\section{Hyponatraemia in congestive heart failure during treatment with captopril}

The oral converting-enzyme inhibitor captopril shows promise in the treatment of cardiac failure. We used the drug in five patients with congestive heart failure that had proved unresponsive to conventional treatment and observed a clear-cut fall in plasma sodium concentration.

\section{Methods and results}

We studied five men aged 54-72 years with congestive heart failure (New York Heart Association functional class III or IV) secondary to coronary artery disease. All had previously received conventional medications, including vasodilators, without success. Throughout the seven-day study they received a constant dietary intake of sodium $(33-48 \mathrm{mmol}(\mathrm{mEq}) /$ day $)$ and potassium $(73-100 \mathrm{mmol}(\mathrm{mEq}) /$ day; body posture was restricted to the supine and sitting positions in bed; and their regular doses of digoxin $(62 \cdot 5-250 \mu \mathrm{g} /$ day) and frusemide (80-500 $\mathrm{mg} /$ day) were continued. All other drugs were stopped at least five days before the study. After a two-day run-in period captopril was administered by mouth in an eight-hourly incremental regimen $(6 \cdot 25-150 \mathrm{mg} /$ dose $)$, and blood was drawn one hour after each dose increase for measurement of plasma electrolyte and hormone concentrations.

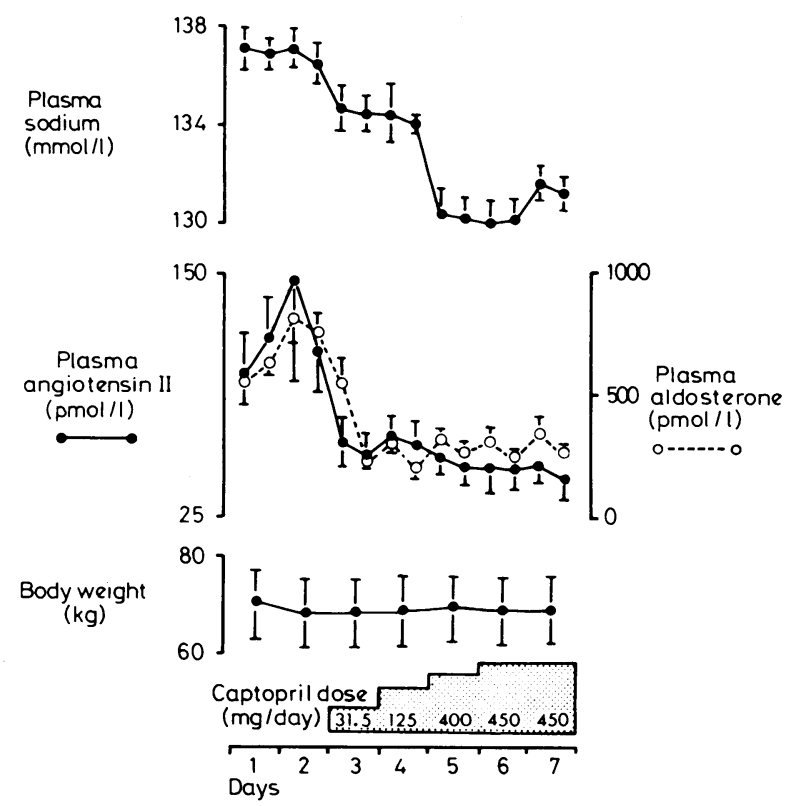

Mean ( \pm SEM) plasma concentrations of sodium, angiotensin II, and aldosterone and body weight in five patients before and during treatment with captopril for cardiac failure.

Conversion: SI to traditional units-Sodium: $1 \mathrm{mmol} / \mathrm{l}=1$ $\mathrm{mEq} / \mathrm{l}$. Angiotensin II: $1 \mathrm{pmol} / 1 \approx 1 \mathrm{pg} / \mathrm{ml}$. Aldosterone: $1 \mathrm{pmol} / 1 \approx 36 \mathrm{pg} / 100 \mathrm{ml}$.

Captopril induced a well-defined fall in plasma sodium concentration, which reached a nadir $7 \mathrm{mmol} / \mathrm{l}$ below baseline values on the third and fourth days of treatment (figure). Plasma concentrations of angiotensin $\mathrm{II}^{1}$ and aldosterone ${ }^{2}$ declined in parallel with those of sodium (figure), and for all data $(n=70)$ significant relations between plasma concentrations of angiotensin II and sodium $(r=0.43, p<0.001)$ and between concentrations of aldosterone and sodium $(r=0.37, p<0.001)$ were observed. In contrast to the decline in plasma sodium, angiotensin II, and aldosterone concentrations, plasma renin activity increased appreciably. For all data $(n=70)$ there was a significant reciprocal relation between plasma renin activity and concurrent plasma sodium concentrations $(r=-0.53, p<0.001)$. Plasma potassium concentrations also rose, from a mean $( \pm$ SEM) of $3.55 \pm 0.16 \mathrm{mmol} / 1$ before treatment to $4 \cdot 40 \pm 0 \cdot 13 \mathrm{mmol} / 1$ on the fifth day of treatment.

Treatment with captopril did not alter cumulative sodium balance or body weight (figure). Haemodynamic improvement occurred in all patients during treatment, and no symptoms attributable to hyponatraemia were observed.

\section{Comment}

We found that plasma sodium concentration fell when captopril was used to treat resistant heart failure. A parallel decline in circulating concentrations of angiotensin II and aldosterone and reciprocal increments in plasma renin activity and plasma potassium concentrations were noted. It is tempting to relate the fall in plasma sodium and the rise in plasma potassium concentrations to the decrease in aldosterone concentrations, since similar though less pronounced electrolyte changes are seen during treatment with spironolactone in congestive heart failure. ${ }^{3}$ Interestingly, frank hyponatraemia is not often observed in the syndrome of hyporeninaemic hypoaldosteronism unless there is coincidental sodium restriction or volume depletion. ${ }^{4}$ Since angiotensin II can stimulate thirst, release of antidiuretic hormone, and water retention by the kidneys, ${ }^{5}$ a fall in angiotensin II taken alone might be expected to result in a rise rather than a fall in plasma sodium concentration. Whatever the mechanisms entailed, plasma sodium as well as potassium concentrations should be monitored during captopril treatment in cardiac failure.

We thank Dr John Carson (Squibb Company) for supplying captopril, Mrs P Gilson for secretarial help, and Mrs Daphne Hinton for measuring electrolyte concentrations. The study received support from the Medical Research Council of New Zealand and the National Heart Foundation of New Zealand.

Requests for reprints should be addressed to Dr M G Nicholls, Medical Unit, Princess Margaret Hospital, Christchurch 2, New Zealand.

${ }^{1}$ Nicholls MG, Espiner EA. A sensitive, rapid radioimmunoassay for angiotensin II. N $Z$ Med $\mathcal{F} 1976 ; 83: 399-403$.

${ }^{2}$ Nicholls MG, Espiner EA, Donald RA, Hughes H. Aldosterone and its regulation during diuresis in patients with gross congestive heart failure. Clin Sci Mol Med 1974;47:301-15.

${ }^{3}$ Nicholls MG, Espiner EA, Hughes H, Rogers T. Effect of potassiumsparing diuretics on the renin-angiotensin-aldosterone system and potassium retention in heart failure. Br Heart $\mathcal{f} 1976 ; 38: 1025-30$.

${ }^{4}$ Phelps KR, Lieberman RL, Oh MS, Carroll HJ. Pathophysiology of the syndrome of hyporeninemic hypoaldosteronism. Metabolism 1980;29: $186-99$.

${ }^{5}$ Brown JJ, Lever AF, Davies DL, Robertson JIS. Renin and angiotensin. A survey of some aspects. Postgrad Med 7 1966;42:153-76.

\section{(Accepted 22 fuly 1980)}

Endocrinology and Cardiology Departments, Princess Margaret Hospital, Christchurch, New Zealand

M G NICHOLLS, MD, FRACP, specialist consultant physician

E A ESPINER, MD, FRACP, professor of medicine

H IKRAM, MD, FRCPE, head, department of cardiology

A H MASLOWSKI, MB, MRACP, senior registrar, department of cardiology

\section{Diagnosis and cure of recurrent urinary infection with microaerophilic and anaerobic bacteria}

There has recently been considerable speculation whether microaerophilic ${ }^{1}$ and anaerobic bacteria ${ }^{2}$ cause urinary tract infections. We describe a patient who repeatedly had "sterile pyuria" whom we found to be suffering from repeated infections caused by microaerophilic and anaerobic organisms.

\section{Case report}

A 76-year-old fit-looking and active woman with a 13-year history of urinary tract infection caused by Escherichia coli and Proteus spp first attended our clinic in October 1978. An ileocystoplasty had been carried out in May 1966 to increase her bladder capacity. Her non-functioning right kidney (extensively calcified and containing a large staghorn calculus) had been removed in January 1972 . We found raised serum urea $(15.7 \mathrm{mmol} / \mathrm{l}$ 